\title{
MICROPROPAGAREA SPECIEI Vaccinium macrocarpon AITON (soiul Piligrim)
}

\author{
Chiţan Raisa \\ Grădina Botanică Națională (Institut) „Alexandru Ciubotaru”, Chișinău, Republica Moldova \\ e-mail: ninaciorchina@mail.ru
}

Merişorul cranberry (nord-american) Vaccinium macrocarpon Aiton soiul 'Piligrim', un soi foarte productiv cu fructul mare pană la 2,0 cm, originar din America de Sud, este un arbust cu înălţimea circa $20-30 \mathrm{~cm}$, cu fructele roşii, frunzele veşnic verzi si florile de culoare albă sau roz pal. Crește cu dificultate în zonele cu veri caniculare, preferând zonele montane și submontane, areal împădurit și solurile acide, constant umede. Nu tolerează solurile alcaline.

Fructele au un conţinut sporit de proteine, contin Provitamina $A$, vitamine $B_{1}, B_{2}, C$, (retinol, acid ascorbic, tocoferol, niacina, piridoxina), minerale (potasiu, fosfor, calciu), tanine (substanţe antibacteriene si antimicotice), fibre, flavonoide (substanţe cu efect antioxidant), saponine, fenoli si acizi graşi esenţiali Omega 3, 6 si 9, uleiuri si zahăruri, ele ofera energie, ajuta la eliminarea stresului, depresiei, oferind sănătate mentala şi îmbunătăţirea memoriei. Merişorul cranberry se înmulţeşte în mod natural prin stoloni (tulpini plagiotrope).

Cercetările au fost efectuate în cadrul Laboratorului de Embriologie şi Biotehnologie a Grădinii Botanice Naţionale (Institut) „Alexandru Ciubotaru”. Scopul cercetărilor elaborarea tehnologiilor de înmulţire prin microclonare şi micropropagare a speciei Vaccinium macrocarpon Aiton, aclimatizarea şi adaptarea plantelor multiplicate prin cultura in vitro la condiţiile ex vitro.

Pentru microclonarea plantelor de Vaccinium macrocarpon Aiton a fost folosit mediu nutritiv Woody Plant Medium gelificat cu agar, WPM - 100\% suplinit cu zeatină $-0,5 \mathrm{mg} / \mathrm{l}$, zaharoză - 30 g/l, agar - 5 g/l, pH - 5,0. După o perioadă de incubare în camera de creştere (circa o lună) s-a observat alungirea lăstarilor axilari şi apariţia noilor lăstari, totuşi (spre deosebire de Vaccinium vitisidaea L.) majoritatea plantulelor nu au format microcloni (dezvoltându-se doar în înălţime), sau doar 1-3 microcloni la un inocul.

Pentru rizogeneza microbutaşilor s-au folosit două variante de medii:1) WPM -100\% adiţionat cu AIA - 0,2 mg/l, zahăr alimentar - 30 g/l, pH - 5,0 şi 2) WPM -100\% adiţionat cu AIB - 0,5 mg/l, zahăr alimentar $-30 \mathrm{~g} / \mathrm{l}, \mathrm{pH}-5,0$. Procesul de rizogeneză a avut loc în partea bazală a minibutaşilor şi a fost influenţat de temperatura din camera de incubare $\left(1 \mathrm{a} 25^{\circ} \mathrm{C}\right.$ procesul de formare a rădăcinilor durează 2-3 luni, la circa $30^{\circ} \mathrm{C}$ doar o lună). Minibutaşii de Vaccinium macrocarpon Aiton (soiul 'Piligrim') au avut un randament de înrădăcinarea de circa $90-100 \%$ pe ambele medii rizogene.

Aclimatizarea şi înrădăcinarea ex vitro a plantulelor de Vaccinium macrocarpon Aiton (soiul 'Piligrim') provenite din cultura in vitro, a fost efectuată în terenul protejat al Laboratorului de Embriologie şi Biotehnologie. Vitroplantulele înrădăcinate au fost spălate cu soluţie slabă de permanganat de potasiu $\left(\mathrm{KMnO}_{4}-0,03 \%\right)$ şi înserate în containere cu amestec de turbă acidă $(\mathrm{pH}$ 3,5-5,0) şi perlit, moderat umezit, în raport 2:1. Fragmentele de lăstari neînrădăcinaţi au fost plantate în containere cu perlit. Aceste containere, în prima fază de aclimatizare, pentru menţinerea umidităţii corespunzătoare, au fost acoperite cu folie transparentă perforată pulverizată cu apa distilată. Pentru ca plantulele de merişor să se adapteze treptat la condițiile ex vitro e necesar menţinerea lor sub folii transparente timp de 30-35 zile. În această perioadă este necesar de aerisit plantulele de câteva ori pe parcursul zilei (de la 10-15 min. la începutul perioadei de aclimatizare până la câteva ore la sfîrşitul ei). Aclimatizarea s-a produs mai bine în lunile de primăvară şi începutul verii (în comparaţie cu lunile de iarnă). 